\title{
Pembelajaran Kooperatif Tipe STAD dalam Peningkatan Minat Belajar dan Disiplin Siswa di SDN 18 Baruga
}

\section{Hartin} Dinas Pendidikan dan Kebudayaan Kota Kendari
email: hartin_tina@yahoo.com

\begin{abstract}
Abstrak
Peserta didik di sekolah dasar adalah insan yang sedang membentuk fondasi fisik dan mental spritual. Secara fisik mereka dikenalkan tentang keutamaan kebugaran jasmani dalam menopang praktik pembelajaran. Secara psikis mereka membutuhkan sentuhan kejiwaan agar tumbuh semangat yang tinggi dalam belajar. Perhatian terpadu pada kebutuhan fisik dan psikis siswa akan menjadikan proses pendidikan yang dilakukan berlangsung secara simbang. Para guru menjadi pelaku utama pembinaan siswa secara komprehensif tersebut. Berbagai pendekatan inovatif dan kreatif mesti dilakukan dan dikembangkan agar siswa dapat berkembang seutuhnya. Perlakuan ini utamanya dilakukan dalam proses pembelajaran melalui penggunaan pendekatan pembelajaran yang relevan. Melalui proses pengamatan yang cukup panjang, keterlibatan peneliti secara langsung secara interaktif baik dengan guru maupun siswa, ditemukan beberapa hal positif dalam pendekatan pembelajaran di SDN 18 Baruga. Aspek yang diangkat dalam catatan ini adalah minat belajar dan disiplin siswa, yang pada awalnya merupakan masalah yang sulit dipecahkan. Namun, para guru terus-menerus melakukan perbaikan-perbaikan dalam proses pembelajaran dengan mengujicobakan beberapa pendekatan pembelajaran yang dapat menjadi jalan keluar atas masalah kesiswaan tersebut. Salah satunya adalah penggunaan metode pembelajaran kooperatif tipe STAD. Dengan menggunakan model percobaan maupun tindakan, penggunaan metode pembelajaran koperatif tipe STAD dapat meningkatkan minat belajar maupun disiplin siswa di SDN 18 Baruga.
\end{abstract}

\section{Kata Kunci: Pembelajaran Aktif Tipe STAD, Minat, Disiplin}




\title{
STAD Type Cooperative Learning in Increasing Students' Interest in Learning and Discipline at SDN 18 Baruga
}

\author{
Hartin \\ Dinas Pendidikan dan Kebudayaan Kota Kendari \\ email: hartin_tina@yahoo.com
}

\begin{abstract}
Students in elementary school are human beings who are forming a physical and mental spiritual foundation. Physically they are introduced to the importance of physical fitness in sustaining learning practices. Psychologically they need a psychological touch so that they grow up in high spirits in learning. Integrated attention to the physical and psychological needs of students will make the educational process carried out in a balanced manner. The teachers become the main actors in comprehensively developing students. Various innovative and creative approaches must be made and developed so that students can develop fully. This treatment is mainly carried out in the learning process through the use of relevant learning approaches. Through a lengthy observation process, the involvement of researchers directly interactively both with teachers and students, found a number of positive things in the learning approach at SDN 18 Baruga. The aspect raised in this note is the interest in learning and student discipline, which was initially a difficult problem to solve. However, the teachers continually make improvements in the learning process by experimenting with several learning approaches that can be a solution to the student problem. One of them is the use of the STAD type cooperative learning method. By using both experimental and action models, the use of the STAD type cooperative learning method can increase student learning interest and discipline at SDN 18 Baruga.
\end{abstract}

Keywords: STAD Type Active Learning, Interest, Discipline 


\section{Pendahuluan}

Sebagai jabatan profesional guru harus mempunyai keterampilan dan kemampuan dalam merancang suatu pembelajaran dan cara mengajarkannya kepada siswa ${ }^{1}$. Pembelajaran siswa aktif dalam hal ini adalah pembelajaran yang dapat mewujudkan keaktifan peserta didik dalam suatu pembelajaran ${ }^{2}$. Mewujudkan hal tersebut, maka seorang guru harus dapat membangkitkan minat murid dalam mempelajari sesuatu, guru harus mampu menciptakan suasana dan kondisi yang memungkinkan siswa untuk melakukan proses belajar, serta guru harus mengetahui kesulitan-kesulitan yang dihadapi oleh siswa sehinga guru dapat memberikan bimbingan untuk mengatasi masalah tersebut ${ }^{3}$.

Pencapaian prestasi belajar siswa dapat dipengaruhi oleh dua faktor, yakni faktor internal dari dalam diri siswa dan faktor eksternal dari luar diri siswa. Minat merupakan salah satu faktor internal yang berpengaruh dalam pencapaian prestasi belajar siswa. Minat dalam belajar siswa mempunyai fungsi sebagai kekuatan yang mendorong siswa untuk belajar ${ }^{4}$. Minat adalah suatu rasa lebih suka dan rasa ketertarikan pada suatu hal atau aktifitas, tanpa ada yang menyuruh". Minat pada dasarnya adalah penerimaan antara diri sendiri dengan

1 Sanaky, Hujair AH. Setifikasi dan Profesionalisme Guru di Era Reformasi Pendidikan. Islamic University of Indonesia, 2005. Banding dengan Supriadi, Oding. "Pengembangan profesionalisme guru sekolah dasar." Jurnal Tabularasa 6, no. 1 (2009): 27-38.

${ }^{2}$ Sani memandang perlunya guru mengembangkan inovasi pembelajaran. Lihat Sani, Ridwan Abdullah. "Inovasi pembelajaran." Jakarta: Bumi Aksara (2013). Terkait dengan pembelajaran Aktif, Nurdyansyah menemukan bahwa pembelajaran aktif dapat digunakan dalam peningkatan hasil belajar pada siswa di Madrasah Ibtidaiyah. Lihat Nurdyansyah, Nurdyansyah, and Toyiba Fitriyani. "Pengaruh Strategi Pembelajaran Aktif Terhadap Hasil Belajar Pada Madrasah Ibtidaiyah." Universitas Muhammadiyah Sidoarjo (2018).

${ }^{3}$ Solusi atas masalah-masalah belajar yang dihadapi siswa salah satunya melalui penggunaan berbagai model pembelajaran. Lihat Fathurrohman, Muhammad. "Model-Model Pembelajaran." Universitas Negeri Yogyakarta. Jogjakarta: Ar-Ruzz Media. Retrieved from (2015).

${ }^{4}$ Nuchiyah, Nunu. "Pengaruh Kepemimpinan Kepala Sekolah dan Kinerja Mengajar Guru Terhadap Prestasi Belajar Siswa." Jurnal Pendidikan Dasar 5, no. 7 (2007): 1-4. 
sesuatu di luar diri yang saling berpengaruh. Semakin kuat atau dekat pengaruh tersebut, akan semakin besar minatnya ${ }^{5}$.

Kurangnya minat belajar sejalan dengan rendahnya kedisiplinan siswa. Hal ini ditunjukan oleh sikap siswa yang tidak patuh terhadap aturan yang berlaku dikelas. Banyaknya tindakan kekerasan dan bullying yang dilakukan siswa terhadap teman sekelasnya. Disiplin memiliki peranan yang sangat penting dalam kehidupan manusia terutama siswa dalam hal belajar karena dengan adanya disiplin siswa mampu mengarahkan diri, mengendalikan perilakunya dan memiliki ketaatan dalam dirinya sendiri. Disiplin juga memberikan kontribusi dalam kegiatan belajar karena dengan disiplin anak memiliki semangat dan kemauan yang keras untuk belajar ${ }^{6}$. Anak yang memiliki kedisiplinan belajar akan menunjukkan ketaatan dan keteraturan terhadap perannya sebagai seorang pelajar yaitu belajar secara terarah dan teratur serta membentuk karakter siswa menjadi siswa yang semangat dan mempunyai kemauan keras untuk belajar. Cara untuk dapat mengatasi keadaan kedisiplinan di sekolah siswa membutuhkan suatu mekanisme yang dapat membantu dalam mengarahkan perilakunya yaitu dengan memiliki kontrol diri ${ }^{7}$.

Penelusuran penulis di SDN 18 Baruga, masalah yang terjadi seperti sebagian besar siswa tidak siap jika ada ulangan mendadak, dari hasil catatan pribadi guru menyebutkan bahwa setiap kali guru meminta untuk mengumpulkan pekerjaan rumah (PR) sekitar 50\% dari 28 siswa tidak mengerjakan pekerjaan rumah (PR). Perilaku siswa yang demikian disebabkan karena kurangnya kesadaran siswa akan pentingnya belajar selama mereka di rumah, siswa kurang dapat mengarahkan dan mengendalikan perilakunya sehingga menunjukkan ketidakdisiplinan belajar. Temuan lainnya adalah siswa yang berminat terhadap pembelajaran sebesar $58,5 \%$ siswa presentase siswa yang disiplin sebesar $57 \%$.

${ }^{5}$ Siagian, Roida Eva Flora. "Pengaruh minat dan kebiasaan belajar siswa terrhadap prestasi belajar matematika." Formatif: Jurnal Ilmiah Pendidikan MIPA 2, no. 2 (2015).

6 Aulina, Choirun Nisak. "Penanaman disiplin pada anak usia dini." PEDAGOGIA: Jurnal Pendidikan 2, no. 1 (2013): 36-49.

7 Zahrifah, Fitria Lailatus, and Eko Darminto. "Penggunaan Strategi Pengelolaan Diri untuk Meningkatkan Disiplin Belajar Siswa." Psikologi Pendidikan dan Bimbingan 12, no. 1 (2011). 
Meskipun demikian, masalah-masalah belajar yang dihadapi tersebut tidak membuat para guru menurun perhatiannya, sebaliknya sebagian guru berupaya melakukan inovasi-inovasi dan terobosanterobosan dalam pembelajaran. Mereka telah memiliki kesadaran untuk mengakses metode-metode baru seperti pembelajaran aktif dan kooperatif. Dalam tulisan ini, praktik pembelajaran yang disoroti adalah penggunaan model Pembelajaran Tipe STAD (Student Team Achievement Division). Dengan kata lain, melalui Model Pembelajaran Tipe STAD siswa akan merasa materi yang diberikannya lebih jelas dan pembelajaran lebih menarik bila dibandingkan hanya dengan membaca buku atau mendengarkan penjelasan guru.

\section{Hasil Belajar dan Berbagai Aspeknya}

Cronbach mengatakan bahwa belajar ditampilkan melalui perubahan sikap sebagai sebuah akibat dari pengalaman ${ }^{8}$. Sejalan dengan pandangan tersebut Skinner menyatakan bahwa belajar adalah perolehan perubahan tingkah laku yang relative dan menetap sebagai akibat dari pengalaman dan latihan ${ }^{9}$. Sedangkan Hilgard menyatakan bahwa belajar merupakan suatu proses dimana suatu kegiatan diubah atau berasal melalui suatu prosedur pendidikan ${ }^{10}$. Ada 4 faktor yang mempengaruhi belajar yaitu faktor nonsosial, sosial, fisiologis, dan psikologis ${ }^{11}$.

Faktor non sosial adalah faktor yang mempengaruhi proses belajar yang tak terbilang jumlahnya yang berasal dari luar diri manusia seperti hujan, buku-buku, alat peraga, keadaan suhu, cuaca, dan sebagainya. Faktor sosial adalah faktor yang dapat mempengaruhi proses pembelajaran seperti faktor manusia (baik ada maupun tidak langsung hadir). Kehadiran orang tersebut sering kali mengganggu poses pembelajaran. Faktor fisiologis dibagi menjadi dua yaitu

${ }^{8}$ Suryabrata, Sumadi. "Proses Belajar Mengajar di Perguruan Tinggi." Yogyakarta: Andi Ofset (1983).

${ }^{9}$ Aditya, Dedy Yusuf. "Pengaruh Penerapan Metode Pembelajaran Resitasi terhadap Hasil Belajar Matematika Siswa." SAP (Susunan Artikel Pendidikan) 1, no. 2 (2016).

${ }^{10}$ Sjukur, Sulihin B. "Pengaruh blended learning terhadap motivasi belajar dan hasil belajar siswa di tingkat SMK." Jurnal pendidikan vokasi 2, no. 3 (2012).

${ }^{11}$ Aritonang, Keke T. "Minat dan motivasi dalam meningkatkan hasil belajar siswa." Jurnal pendidikan penabur 7, no. 10 (2008): 11-21. 
keadaan tonus jasmani dan keadaan fungsi fisiologis. Keadaan tonus jasmani $^{12}$.

\section{a. Minat belajar}

Minat adalah suatu rasa suka dan rasa ketertarikan pada suatu hal atau Aktivitas, tanpa ada yang menyuruh dan cenderung untuk memberikan perhatian yang lebih besar terhadap hal atau aktivitas tersebut $^{13}$. Minat sebagai suatu pemusatan perhatian yang tidak disengaja terlahir dengan penuh kemauannya dan tergantung dari bakat serta lingkungannya ${ }^{14}$.

Dapat disimpulkan bahwa minat belajar dapat didefinisikan sebagai ketertarikan dari diri siswa dalam pembelajaran sebagai wujud kemauan untuk melaksanakan suatu kegiatan belajar dengan ciri timbulnya perasaan senang, perhatian, dan aktivitas dalam melaksanakan kegiatan tersebut.

Minat yang kuat akan menimbulkan usaha yang gigih serius dan tidak mudah putus asa dalam menghadapi tantangan. Jika seseorang siswa memiliki rasa ingin belajar, ia akan cepat dapat mengerti dan mengingatnya. Fungsi minat bagi kehidupan anak, salah satunya yaitu minat sebagai pendorong tenaga yang kuat serta prestasi selalu dipengaruhi oleh jenis dan intensitas minatnya ${ }^{15}$. Tidak adanya minat seseorang terhadap suatu pelajaran akan menimbulkan kesulitan belajar. Belajar dengan minat akan mendorong siswa belajar lebih baik daripada belajar tanpa minat. Namun demikian, minat tanpa adanya usaha yang baik maka belajar juga sulit untuk berhasil ${ }^{16}$.

Berdasarkan penjabaran beberapa pendapat di atas dapat disimpulkan bahwa minat merupakan salah satu faktor penting dalam pembelajaran. Belajar dengan dilandasi minat akan memberikan

${ }^{12}$ Kusrini, Woro, and Nanik Prihartanti. "Hubungan Dukungan Sosial dan Kepercayaan Diri dengan Prestasi Bahasa Inggris Siswa Kelas VIII SMP Negeri 6 Boyolali." Jurnal Penelitian Humaniora 15, no. 2 (2014): 131-140.

${ }^{13}$ Astuti, Siwi Puji. "Pengaruh kemampuan awal dan minat belajar terhadap prestasi belajar fisika." Formatif: Jurnal Ilmiah Pendidikan MIPA 5, no. 1 (2015).

${ }^{14}$ Suharyat, Yayat. "Hubungan antara sikap, minat dan perilaku manusia." Jurnal Region 1, no. 3 (2009): 1-19.

${ }^{15}$ Suharyat, Yayat. "Hubungan antara sikap, minat dan perilaku manusia." Jurnal Region 1, no. 3 (2009): 1-19.

16 Aritonang, Keke T. "Minat dan motivasi dalam meningkatkan hasil belajar siswa." Jurnal pendidikan penabur 7, no. 10 (2008): 11-21. 
motivasi tersendiri bagi siswa untuk lebih giat dan tekun dalam PBM sehingga materi pelajaran tersebut dapat lebih mudah diserap dan dipahami oleh siswa. Oleh karena itu menumbuhkan minat belajar pada diri siswa sangat penting.

\section{b. Indikator Minat}

Siswa yang berminat dalam belajar mempunyai ciri-ciri sebagai berikut: (1) mempunyai kecenderungan yang tetap untuk memperhatikan dan mengenang sesuatu yang dipelajarinya secara terus menerus, (2) ada rasa suka dan senang pada sesuatu yang diminati, (3) memperoleh suatu kebanggaan dan kepuasan pada sesuatu yang diminati, (4) ada rasa keterikatan pada sesuatu aktivitasaktivitas yang diminati, (5) lebih menyukai suatu hal yang menjadi minatnya ${ }^{17}$. Pemusatan perhatian yang intensif terhadap materi memungkinkan siswa untuk belajar lebih giat, dan akhirnya mencapai prestasi yang diinginkan. Berdasarkan pendapat diatas, disimpulkan bahwa ciri-ciri minat belajar terdiri dari: adanya perhatian, rasa suka dan senang, dan ada rasa keterikatan terhadap aktivitas yang diminatinya ${ }^{18}$.

Ciri-ciri minat belajar dapat juga dijadikan sebagai indikator minat belajar, sebab ciri-ciri minat di atas senada dengan indikator minat yaitu ekspresi perasaan senang, perhatian dalam belajar, kemauan mengembangkan diri, dan keterlibatan siswa dalam pembelajaran ${ }^{19}$.

Berdasarkan pemaparan beberapa teori di atas dapat disimpulkan bahwa ada empat indikator minat belajar yang digunakan dalam penelitian ini yaitu (a) perasaan senang dan suka terhadap pembelajaran, (b) usaha untuk mengembangkan diri, (c) perhatian dalam pembelajaran, (d) keterlibatan dalam pembelajaranPeneliti hanya mengambil empat indikator ini karena pemaparan mengenai

${ }^{17}$ Nurhasanah, Siti, and A. Sobandi. "Minat belajar sebagai determinan hasil belajar siswa." Jurnal pendidikan manajemen perkantoran 1, no. 1 (2016): $135-142$

${ }^{18}$ Hasanah, Ummi, Riska Ahmad, and Yeni Karneli. "Efektivitas Layanan Penguasaan Konten untuk Meningkatkan Konsentrasi Belajar Siswa." (2017): 143148.

19 Fimansyah, Dani. "Pengaruh Strategi Pembelajaran Dan Minat Belajar Terhadap Hasil Belajar Matematika." JUDIKA (JURNAL PENDIDIKAN UNSIKA) 3, no. 1 (2015). 
ciri-ciri minat belajar menurut Slameto, Syah dan Joko memiliki kesamaan dan mewakili teori indikator minat belajar.

\section{c. Disiplin}

Indikator-indikator kedisiplinan yaitu: a) hadir tepat waktu, b) patuh menjalankan aturan-aturan, dan c) tertib dalam menaati aturanaturan. Seseorang dapat dikatakan disiplin apabila ia mematuhi dan tertib dalam menjalankan peraturan-peraturan yang $\mathrm{ada}^{20}$. Disiplin merupakan suatu tindakan yang menunjukan perilaku tertib dan patuh dalam berbagai ketentuan dan peraturan. Selain itu disiplin merupakan kemampuan seseorang menunjukan hal yang terbaik dalam segala situasi melalui pengontrolan emosi, kata-kata, dorongan, keinginan, dan tindakan. Kedisiplinan tidak hanya kepatuhan seseorang terhadap aturan yang berlaku tetapi juga berkaitan dengan sikap, perilaku, dan kata-kata seseorang ${ }^{21}$. Dapat juga dikatakan bahwa disiplin yaitu peraturan-peraturan atau tata tertib (di sekolah, ketentaraan, dsb) yang ditetapkan untuk melatih seseorang supaya berperilaku baik dan ketaatan atau kepatuhan pada peraturan-peraturan, tata tertib yang telah ditetapkan. Kedisiplinan tidak hanya tertib maupun disiplin menjalankan aturan tetapi juga melatih seseorang dalam berperilaku baik, taat, dan patuh dengan aturan-aturan ${ }^{22}$. Maka indikator disiplin yaitu a) tertib, b) patuh, dan c) perilaku baik.

\section{d. Pembelajaran Kooperatif}

Kooperatif mengandung pengertian bekerja bersama dalam mencapai tujuan bersama ${ }^{23}$. Menurut Rusman, pembelajaran kooperatif merupakan bentuk pembelajaran dengan cara siswa belajar dan bekerja dalam kelompok-kelompok kecil secara kolaboratif yang

${ }^{20}$ Chulsum, Umi. "Pengaruh Lingkungan Keluarga, Kedisiplinan Siswa, Dan Motivasi Belajar Terhadap Hasil Belajar Ekonomi Siswa Di SMA Negeri 7 Surabaya." Jurnal ekonomi pendidikan dan Kewirausahaan 5, no. 1 (2017): 5-20.

21 Aulina, Choirun Nisak. "Penanaman disiplin pada anak usia dini." PEDAGOGIA: Jurnal Pendidikan 2, no. 1 (2013): 36-49.

${ }^{22}$ Sidanti, Heny. "pengaruh lingkungan kerja, disiplin kerja dan motivasi Kerja terhadap kinerja pegawai negeri sipil di Sekretariat DPRD kabupaten madiun." Jurnal Jibeka 9, no. 1 (2015): 44-53.

23 Suwastana, I. Wayan. "Penerapan Pembelajaran Melalui Model Kooperatif Numbered Heads Together Siswa Kelas V SDN No 1 Tonggolobibi Untuk Meningkatkan Prestasi Belajar PKn." Jurnal Kreatif Tadulako 4, no. 1 (2016). 
anggotanya terdiri dari empat sampai enam orang dengan struktur kelompok yang bersifat heterogen ${ }^{24}$. Slavin mengatakan bahwa cooperative learning adalah suatu model pembelajaran di mana siswa belajar dan bekerja dalam kelompokkelompok kecil secara kolaboratif yang anggotanya terdiri dari 4 sampai 6 orang, dengan struktur kelompoknya yang bersifat heterogen. Selanjutnya dikatakan pula, keberhasilan belajar dari kelompok tergantung pada kemampuan dan aktivitas anggota kelompok, baik secara individual maupun secara kelompok $^{25}$.

Cooperative learning mengandung pengertian sebagai suatu sikap atau perilaku bersama dalam bekerja atau membantu di antara sesama dalam struktur kerja sama yang teratur dalam kelompok, yang terdiri dari dua orang atau lebih dimana keberhasilan kerja sangat dipengaruhi oleh keterlibatan dari setiap anggota kelompok itu sendiri $^{26}$. Sedangkan Sharan menyatakan bahwa pembelajaran kooperatif adalah pendekatan yang berpusat-kelompok dan berpusatsiswa untuk pengajaran dan pembelajaran di kelas ${ }^{27}$. Eggen menyebut pembelajaran kooperatif merupakan sebuah kelompok strategi pengajaran yang melibatkan siswa bekerja secara berkolaborasi untuk mencapai tujuan bersama ${ }^{28}$.

\section{Pembelajaran kooperatif tipe STAD}

Pembelajaran kooperatif tipe STAD (Student Teams Achievement Divisions) merupakan salah satu tipe dari model

${ }^{24}$ Febrina, Nuansa Ayu, and Isroah Isroah. "Peningkatan Aktivitas Belajar Akuntansi Melalui Implementasi Model Pembelajaran Kooperatif Tipe Student Teams Achievement Division (STAD) Pada Siswa Kelas X Ak 3 Program Keahlian Akuntansi SMK Batik Perbaik Purworejo Tahun Ajaran 2011/2012." Jurnal Pendidikan Akuntansi Indonesia 10, no. 2 (2012).

${ }^{25}$ KRITIS, BERPIKIR, and DAN PENGUASAAN KONSEP DALAM KONSEP FOTOSINTESIS. "A. Pembelajaran Kooperatif." (2003).

${ }^{26}$ Kusumaningsih, Kiki Dwi. "Pengaruh Model Pembelajaran Kooperatif Tipe Teams-Games-Tournaments (TGT) Terhadap Peningkatan Hasil Belajar Biologi Pada Konsep Sistem Pencernaan Manusia." Jurnal Ilmiah Exacta 2, no. 1 (2009).

${ }^{27}$ Rofiq, M. Nafiur. "Pembelajaran kooperatif (cooperative learning) dalam pengajaran pendidikan agama Islam." Jurnal Falasifa 1, no. 1 (2010): 1-14.

${ }^{28}$ Astuti, Y., and Beni Setiawan. "Pengembangan lembar kerja siswa (LKS) berbasis pendekatan inkuiri terbimbing dalam pembelajaran kooperatif pada materi kalor." Jurnal Pendidikan IPA Indonesia 2, no. 1 (2013). 
pembelajaran kooperatif dengan menggunakan kelompok-kelompok kecil dengan jumlah anggota tiap kelompok 4-5 orang siswa secara heterogen ${ }^{29}$. Ditegaskan Slavinmenjelaskan bahwa pembelajaran kooperatif dengan model STAD, siswa ditempatkan dalam kelompok belajar beranggotakan empat atau lima orang siswa yang merupakan campuran dari kemampuan akademik yang berbeda, sehingga dalam setiap kelompok terdapat siswa yang berprestasi tinggi ${ }^{30}$.

Dapat disimpulkan bahwa pembelajaran kooperatif tipe STAD (Student Teams Achievement Divisions) merupakan salah satu tipe dari model pembelajaran kooperatif dimana pada penerapannya dalam pembelajaran siswa ditempatkan dalam tim belajar yang beranggotakan 4-5 orang yang berbeda, baik berbeda menurut tingkat prestasi, jenis kelamin, kelompok ras/etnis, atau kelompok sosial lainnya

\section{a. Karakteristik pembelajaran kooperatif tipe STAD (student teams achievement divisions)}

Pembelajaran STAD ini hampir sama dengan pembelajaran kooperatif lainnya namun yang membedakan adalah tipe STAD ini menggunakan kuiskuis individual pada tiap akhir pelajaran. Para siswa tidak diperbolehkan untuk saling membantu dalam mengerjakan kuis sehingga tiap siswa bertanggung jawab secara individual untuk memahami materinya. Pembelajaran kooperatif tipe STAD ini terdiri atas enam komponen utama di antaranya adalah penyampaian tujuan dan motivasi, pembagian kelompok, presentasi dari guru, kegiatan belajar dalam tim (kerja tim), kuis (evaluasi), dan penghargaan prestasi $\operatorname{tim}^{31}$.

\section{b. Karakteristik anak kelas V}

Masa usia sekolah dasar kelas V sebagai masa kanak-kanak akhir yang berlangsung dari usia sepuluh tahun hingga kira-kira usia

${ }^{29}$ Nugroho, U., and S. S. Edi. "Penerapan pembelajaran kooperatif tipe STAD berorientasi keterampilan proses." Jurnal Pendidikan Fisika Indonesia 5, no. 2 (2009).

${ }^{30}$ Chairani, Zahra. "Scaffolding dalam pembelajaran matematika." Math Didactic: Jurnal Pendidikan Matematika 1, no. 1 (2015).

${ }^{31}$ Lubis, Asneli. "Pengaruh Model Pembelajaran Kooperatif Tipe STAD Terhadap Hasil Belajar Fisika Siswa Pada Materi Pokok Gerak Lurus di Kelas X SMA Swasta UISU Medan." Jurnal Pendidikan Fisika 1, no. 1 (2012): 27-32. 
sebelas tahun atau dua belas tahun. Karakteristik utama siswa sekolah dasar kelas $\mathrm{V}$ adalah mereka menampilkan perbedaan-perbedaan individual dalam banyak segi dan bidang, di antaranya, perbedaan dalam intelegensi, kemampuan dalam kognitif dan bahasa, perkembangan kepribadian dan perkembangan fisik anak ${ }^{32}$. Menurut Piaget, tahap perkembangan berpikir anak dibagi menjadi empat tahap yaitu 1)Tahap sensorimotorik (0-2 tahun), 2)Tahap praoperasional (27 tahun), 3)Tahap operasional konkret (7-11 tahun), dan, 4)Tahap operasional formal (12-15 tahun) Berdasarkan uraian di atas, siswa kelas V Sekolah Dasar termasuk berada pada tahap operasional konkret dalam berpikir. Anak pada masa operasional konkret sudah mulai menggunakan operasi mentalnya untuk memecahkan masalahmasalah yang aktual. Anak mampu menggunakan kemampuan mentalnya untuk memecahkan masalah yang bersifat konkret ${ }^{33}$.

Kemampuan berpikir ditandai dengan adanya aktivitasaktivitas mental seperti mengingat, memahami, dan memecahkan masalah. Masa anak-anak di Sekolah Dasar menjadi dua fase yaitu masa anak kelas rendah (kelas I sampai dengan kelas 3), dan masa anak kelas tinggi (kelas 4 sampai dengan kelas 6). Masa anak kelas rendah berlangsung antara usia 7-9 tahun, sedangkan masa anak kelas tinggi berlangsung antara usia 9-12 tahun. Kelas IV Sekolah Dasar tergolong pada masa anak kelas tinggi. Anak kelas tinggi Sekolah Dasar memiliki karakteristik sebagai berikut 1) Perhatian tertuju pada kehidupan praktis sehari-hari, 2) Ingin tahu, ingin belajar, dan berpikir realitas, 3) Timbul minat kepada pelajaran-pelajaran khusus, 4)Anak memandang nilai sebagai ukuran yang tepat mengenai prestasi belajarnya di sekolah, 5) Anak-anak suka membentuk kelompok sebaya untuk bermain bersama, mereka membuat peraturan sendiri dalam kelompoknya. Berdasarkan uraian di atas, maka dapat ditarik kesimpulan bahwa untuk meningkatkan minat siswa guru harus

${ }^{32}$ Gunantara, Gede, I. Made Suarjana, and Putu Nanci Riastini. "Penerapan model pembelajaran problem based learning untuk meningkatkan kemampuan pemecahan masalah matematika siswa kelas V." MIMBAR PGSD Undiksha 2, no. 1 (2014).

${ }^{33}$ Rosnawati, R. "Enam tahapan aktivitas Dalam pembelajaran matematika untuk mendayagunakan berpikir tingkat tinggi siswa." In Jurnal disampaikan dalam seminar Nasional dengan tema: "Revitalisasi MIPA dan Pendidikan MIPA dalam Rangka penguasaan. 2009. 
mampu membuat sebuah pembelajan yang menyenagkan dan membangkitkan rasa ingin tau,ingin belajar dan berpikir realistis ${ }^{34}$.

\section{c. Pembelajaran Pkn di SD: Sebuah Ilustrasi}

Untuk mengonsepsikan kembali pendidikan kewarganegaraan dengan paradigmanya yang baru, konsep negara dapat di dekati dari sudut pandang sistem. Memasuki era globalisasi yang mana bangsa Indonesia berada dalam masa transisi atau proses perjalanan bangsa menuju masyarakat madani (civil society), pendidikan kewarganegaraan sebagai salah satu atau mata pelajaran di persekolahan perlu menyesuaikan diri sejalan kebutuhan dan tuntutan masyarakat yang sedang berubah. 20 mampu melaksanakan tugas profesionalnya adalah memahami bagaimana peserta didik belajar dan bagaimana mengorganisasikan proses pembelajaran yang mampu mengembangkan kemampuan dan membentuk watak peserta didik, serta memahami tentang siswa belajar ${ }^{35}$.

Menurut Brunerpada dasarnya belajar merupakan proses kognitif yang terjadi dalam diri seseorang. Ada tiga proses kognitif yang terjadi dalam belajar, yaitu :1. Proses perolehan informasi baru,2. Proses menstranformasi informasi yang diterima, 3. Menguji relevansi dan ketepatan pengetahuan. Perolehan informasi baru dapat terjadi dari kegiatan membaca, mendengarkan penjelasan guru mengenai materi yang diajarkan atau mendengar/melihat audio visual dan lain-lain.Belajar sebagai proses manusiawi memiliki kedudukan dan peran penting, baik dalam kehidupan masyarakat tradisional maupun modern. Pentingnya proses belajar dapat dipahami dari traditional, filsafat, temuan penilitian dan teori tentang belajar ${ }^{36}$.

\section{Penelitian Terdahulu}

Badriyah menjelaskan bahwa penggunaan model pembelajaran kooperatif tipe STAD ini cukup efektif untuk menimbulkan antusias dan motivasi siswa untuk belajar, karena memang karakteristik siswa

34 Syatyawati, Riska. "Hubungan Antara Status Gizi dengan Prestasi Belajar Anak Sekolah Dasar di Desa Grenggeng Kecamatan Karanganyar Kebumen." PhD diss., Universitas Muhammadiyah Surakarta, 2013.

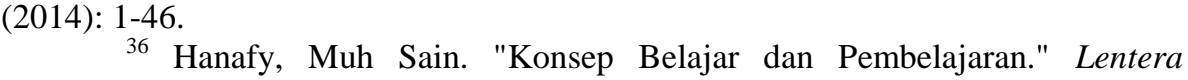
Pendidikan: Jurnal Ilmu Tarbiyah dan Keguruan 17, no. 1 (2014): 66-79. 
SD pada umumnya di antaranya masih suka bermain dan suka membentuk kelompok sebaya. Sehingga dengan menggunakan model pembelajaran ini, siswa dapat selalu berinteraksi dengan siswa lain yang dikemas dalam suatu pembelajaran kelompok dengan tetap dalam bimbingan guru, agar kegiatan kelompok dapat terarah dengan baik. Dengan demikian, siswa tidak hanya duduk, diam dan mendengarkan penjelasan dari guru tetapi siswa ikut aktif dalam proses pembelajaran. Dari hasil penelitian tersebut di atas dapat dilihat bahwa ketuntasan belajar siswa meningkat dari 43,33\% menjadi $80 \%$ dan hasil akhir mencapai 100\%. Hal itu menunjukkan bahwa ketuntasan belajar dari data sebelum tindakan sampai siklus I sampai siklus II ketuntasan belajarnya naik dari 93,33\% menjadi $100 \%$. Kenaikan hasil belajar tersebut menunjukkan bahwa model pembelajaran kooperatif tipe STAD dapat digunakan dalam meningkatkan hasil belajar siswa ${ }^{37}$.

Penyelidikan lainnya dilakukan oleh Hermawan, yang menunjukan bahwa penerapan model pembelajaran kooperatif tipe STAD dapat meningkatkan aktifitas dan hasil belajar. Hal ini ditunjukan dengan peningkatan presentase rata-rata aktivitas siswa dari $58 \%$ pada siklus I menjadi $80 \%$ pada siklus II $^{38}$. Sedangkan presentase ketuntasan belajar meningkat dari $42,5 \%$ pada kondisi awal menjadi $56,4 \%$ pada siklus 1I dan $76,9 \%$ pada siklus II. Sedangkan Melania Endah Kumalasari dengan judul peningkatan kedisiplinan dan prestasi belajar kelas V SDN 01 Baruga 1 mata pelajaran matematika menggunakan pendekatan PMRI. Hasil penelitian menunjukan adanya peningkatan kedisiplinan yang cukup sebesar $75 \%$ yaitu berarti mengalami peningkatan $31,33 \%$ dari kondisi awal $43,66 \%$. Begitupula dengan prestasi belajar meningkat ditunjukan peroilehan nilai siswa yang memenuhi KKM pada siklus II mencapai $78,12 \%$ meningkat sebesar $46,87 \%$ dari kondisi awal 31,25\%.

${ }^{37}$ Badriyah, Nanik. "Penerapan pembelajaran kooperatif tipe STAD untuk meningkatkan hasil belajar IPS siswa kelas V MI Al Hikmah Beji Pasuruan." Penerapan pembelajaran kooperatif tipe STAD untuk meningkatkan hasil belajar IPS siswa kelas V MI Al Hikmah Beji Pasuruan/Nanik Badriyah (2010).

${ }^{38}$ Hermawan, Andri. "Penerapan model pembelajaran kooperatif tipe stad untuk meningkatkan aktivitas dan hasil belajar IPS siswa kelas V SD Negeri Bandulan 05 Malang." Penerapan model pembelajaran kooperatif tipe stad untuk meningkatkan aktivitas dan hasil belajar IPS siswa kelas V SD Negeri Bandulan 05 Malang/Andri Hermawan (2012). 
Penelitian-penelitian di atas menunjukan bahwa sudah ada penelitian sebelumnya mengenai minat belajar, kedisiplinan siswa dan penggunaan pembelajaran kooperatif tipe STAD pada sebuah pembelajaran. Metode tersebut terbukti efektif untuk meningkatkan kualitas sebuah kegiatan pembelajaran.

Penelitian yang telah dijabarkan tersebut relevan dengan penelitian yang akan dilakukan oleh peneliti karena memiliki variable yang sama yaitu minat,disiplin siswa dan penerapan metode pembelajaran STAD.Dalam penelitian di atas belum ada mengenai Meningkatkan Minat Belajar Dan Disiplin Siswa Dengan Menggunakan Metode Pembelajaran Kooperatif Tipe Stad Pada Mata Pelajaran Pkn Kelas V Di SDN 01 Baruga. Maka peneliti akan mengangkat topik penggunaan metode pembelajaran kooperatif tipe STAD untuk meningkatkan minat belajar dan kedisiplinan siswa.

\section{Kerangka Berpikir}

Guru memiliki peran penting dalam proses pemeblajaran karena sebagai fasilitator bagi siswa. Guru lebih dominan di kelas menggunakan metode pembelajaran ceramah. Hal ini yang menyebabkan menurunnya minat belajar siswa terhadap sebuah pembelajaran. Ketika guru memberi tugas, siswa cenderung mengobrol dengan teman. Hal tersebut juga dapat menyebabkan kedisiplinan siswa rendah karena tidak dapat menyelesaikan tugas tepat waktu.

Dalam kegiatan pembelajaran siswa hanya dituntut unrtuk menghafal materi tanpa melakukan atau bekerja. Sehingga proses pembelajaran menjadi tidak bermakna. Cara yang mampu membuat pembelajaran Pkn menjadi bermakna adalah dengan cara membagi siswa dalam beberapa kelompok sehingga terjadi komunikasi antar teman untuk memecahkan permasalahan yang ada. Pembelajaran yang membuat siswa aktif saling membantu dan memotivasi, sehingga pembelajaran menjadi menyenangkan dan mudah. Pembelajaran yang mudah dan menyenangkan tersebut mampu menumbuhkan minat siswa dalam belajar. Selain itu semakin siswa aktif dalam belajar semakin besar pula minat siswa dalam belajar. Menerapkan metode STAD dengan memberikan permasalahan yang ada disekitar siswa untuk didiskusikan akan membuat terjadinya pertukaran pendapat berdasarkan pengalaman siswa di kehidupan sehari-hari. Pembelajaran kooperatif tipe STAD merupakan pembelajaran kooperatif yang 
mengutamakan norma-norma atau aturan baik individu maupun kelompok.

Aturan-aturan dalam pembelajaran harus dipatuhi oleh siswa, melalui pembelajaran yang mengutamakan aturan atau norma tersebut dapat mengembangkan kedisiplinan siswa dalam belajar. Aturanaturan dalam pembelajaran harus dipatuhi oleh siswa, melalui pembelajaran yang mengutamakan aturan atau norma tersebut dapat mengembangkan kedisiplinan siswa dalam belajar. Pembelajaran tanpa adanya aturan atau norma akan membuat proses belajar mengajar tidak berjalan denganbaik. Selain itu pembelajaran PKn mengajarkan tentang pengetahuan, sikap, perilaku, dan keterampilan sosial. Materi pembelajaran PKn mengajarkan tentang perilaku, sikap, keterampilan dan pengetahuan yang berkaitan dengan aturan-aturan. Aturan-aturan dan tanggung jawab dalam pembelajaran tersebut melatih dan menanamkan sikap kedisiplinan pada siswa.Melalui penerapan metode pembelajaran kooperatif tipe STAD dalam mata pelajaran Pkn diharapkan mampu merangsang minat belajar dan kedisiplinan siswa, sehingga dapat meningkatkan pencapaian minat belajar dan kedisiplinan siswa terhadap mata pelajaran PKn.

\section{Metode Penelitian}

Penelitian ini menggunakan pendekatan kualitatif, dimana pengumpulan data dilakukan melalui pengamatan, wawancara, dan studi dokumen. Analisis data menggunakan model dari Miles dan Huberman, yaitu reduksi, display, dan verifikasi ${ }^{39}$. Pengamatan dilakukan atas tindakan pembelajaran yang dilakukan oleh para guru di SDN 18 Baruga. Pengamatan dilakukan ketika para guru melakukan tindakan pembelajaran di kelas. Kegiatan yang dilakukan oleh guru tersebut dapat digolongkan sebagai proses penelitian tindakan kelas.

Penelitian tindakan kelas merupakan penelitian yang sangat tepat untuk meningkatkan kualitas pembelajaran dan yang selanjutnya

39 Sugiyono. Metode penelitian pendidikan:(pendekatan kuantitatif, kualitatif dan $R \& D$ ). Alfabeta, 2008. Lihat pula Miles, Matthew B., and A. Michael Huberman. "Analisis data kualitatif." (1992). Dan Moleong, Lexy J. "Metodologi penelitian kualitatif edisi revisi." Bandung: PT Remaja Rosdakarya 103 (2007). 
dapat meningkatkan kualitas pendidikan secara luas ${ }^{40}$. O'Brien menyatakan bahwa penelitian tindakan kelas adalah penelitian yang dilakukan ketika sekelompok orang (siswa) diidentifikasi permasalahannya kemudian (guru) menetapkan suatu tindakan untuk mengatasinya $^{41}$. Sesuai dengan jenis penelitian yang dipilih yaitu penelitian tindakan kelas, maka penelitian ini menggunakan penelitian dari Kemmis dan targgart yaitu berbentuk spiral dari satu siklus ke siklus berikutnya. Setiap siklus meliputi planning (rencana), action (tindakan), observation (observasi) dan reflection (refleksi). Langkahlangkah yang dilakukan pada siklus berikutnya merupakan perencanaan yang sudah direvisi,tindakan pengamatan dan refleksi. Sebelum melakukan tindakan pada siklus I penelitian melakukan identifikasi permasalahan. Siklus spiral dari tahap-tahap penelitian tindakan kelas yang akan dilakukan peneliti ${ }^{42}$.

\section{Hasil Penelitian dan Pembahasan}

Proses pembelajaran berbasis tindakan yang dilakukan oleh para guru di SDN 18 Baruga, menunjukkan langkah-langkah sistematik sebagai berikut:

\section{Perencanaan}

Perencanaan merupakan suatu kegiatan merencanakan tindakan yang akan dilakukan pada pelaksanaan tindakan. Pada tahap perencanaan mencakup beberapa hal antara lain: (a) identifikasi masalah, (b) analisis penyebab adanya masalah, dan (c) pengembangan bentuk tindakan yang akan dilakukan sebagai pemecahan masalah.

\section{Pelaksanaan}

Pelaksanaan pada penelitian tindakan kelas mengacu pada kegiatan yang direncanmakan pada tahap perencanaan. Setelah ditetapkan bentuk pelaksanaan tindakan maka langkah berikutnya

40 Arikunto, Suharsimi. "Penelitian Tindakan Kelas (PTK)." Jakarta: Departemen Pendidikan dan Kebudayaan (2006).

${ }^{41}$ Astrawan, Kadek. "Implementasi Model Pembelajaran Kooperatif Tipe STAD Meningkatkan Aktivitas Dan Hasil Belajar Tolak Peluru." Jurnal Pendidikan Jasmani, Olahraga dan Kesehatan Undiksha 1, no. 1 (2013).

${ }^{42}$ Widayati, Ani. "Penelitian tindakan kelas." Jurnal Pendidikan Akuntansi Indonesia 6, no. 1 (2008). 
adalah mengimplementasikan dalam kegiatan pembelajaran sesuai dengan scenario pembelajaran dan instrumenm yang sudah dibuat.

\section{Observasi}

Obserasi dalam penelitian tindakan kelas adalah kegiatan mengamati kegiatan guru dan siswa selama proses pembelajaran (berbasis tindakan) dengan menggunakan alat pantau (instrumen) pengamatan atau lembar observasi.

\section{Refleksi}

Refleksi merupakan kegiatan perenungan dan diskusi antara guru dengan mitra untuk mengetahui kelemahan-kelemahan dalam proses pembelajaran.

Kegiatan di atas dapat dianggap sebagai bentuk penelitian tindakan kelas dengan penjelasan sebagai berikut:

Subyek Penelitian ini adalah siswa kelas V SD N 18 Baruga yang berjumlah 30 orang. Obyek Penelitian ini adalah minat belajar dan disiplin siswa terhadap tema 4 subtema 1 Pentingya Kesehatan Diri dan Lingkungan menggunakan metode STAD dalam proses pembelajaran kelas V SDN 18 Baruga.

1. Rencana Tindakan

Rencana tindakan pada penelitian ini dibagi menjadi 2 siklus. Setiap siklus menggunakan teknik pembelajaran tipe STAD yaitu pemberian materi, kerja kelompok, kuis dan pemberian penghargaan kepada kelompok ang memiliki prestasi terbaik.

2. Persiapan Penelitian yang dilakukan peneliti sebelum melaksanakan penelitian tindakan antara lain:

a. Peneliti meminta izin untuk melakukan penelitian di SDN 01 Baruga kepada kepala sekolah dan guru kelas V SDN 01 Baruga.

b. Melakukan observasi untuk mengidentifikasi permasalahan yang ada di kelas V.

c. Peneliti mengadakan diskusi dengan guru kelas $\mathrm{V}$ tentang minat dan kedisiplinan siswa dalam mengikuti pembelajaran.

d. Merumuskan permasalahan

e. Menganalisis dan memberi solusi permasalahan yang dihadapi oleh siswa kelas V.

f. Membuat proposal penelitian 
g. Menyiapkan instrument pembelajaran dan intrumen pengumpulan data.

h. Setelah selesai melakukan uji validitas kemudian peneliti melakukan penelitian.

i. Rencana tindakan setiap siklus Penelitian tindakan kelas ini menggunakan model Kemmis dan Tarrgart sesuai dengan langkah-langkahnya yaitu satu siklus terdiri dari empat tahap kegiatan pokok yang akan dilakukan.

Penelitian ini dilakukan dengan 2 siklus. Berkaitan dengan hal tersebut, secara operasional prosedur tindakan kelas diuraikan sebagai berikut:

1. Siklus I

Siklus I dilakukan selama dua kali pembelajaran, setiap pembelajaran terdapat $8 \times 35$ menit. Langkah-langkahnya sebagai berikut

a. Perencanaan tindakan siklus I

Mempersiapkan perangkat pembelajaran dan menyusun perangkat pembelajaran berupa skenario pembelajaran meliputi Rencana Pelaksanaan pembelajaran (RPP), lembar kerja siswa, pretest, posttest, kuis dan media pembelajaran. Setelah itu peneliti menyiapkan instrument penelitian untuk mengukur minat dan disiplin siswa berupa lembar observasi dan kuisioner.

b. Pelaksanaan tindakan siklus I

Pembelajaran 1

1) Guru menyampaikan tujuan pembelajaran yang akan dicapai pada pertemuan hari ini.

2) Siswa mengerjakan pretest untuk mengetahui pengetahuan siswa sebelum mendapatkan materi.

3) Siswa mengumpulkan pretest kepada guru

4) Guru mendorong munculnya ide dan gagasan siswa melalui gambar sungai berair kotor dan sungai berair bersih.

5) Guru bertanya tentang bagaimana cara menjaga kebersihan air?

6) Guru mengkonfirmasi jawaban siswa sebagi pengetahuan awal tentang keterkaitan air bersih dengan kehidupan.

7) Guru membagi kelas menjadi 6 kelompok menggunakan kartu bernomor. 
8) Siswa laki-laki diminta mengambil kartu bernomor lebih dahulu 1 sampai 6 agar terbagi rata menyebar disemua kelompok.

9) Setiap kelompok terdiri dari 4-6 orang siswa yang berbeda baik jenis kelamin, kecerdasan, ataupun usia.

10) Guru membagikan lembar kerja siswa (LKS)

11) Siswa diminta mengerjakan LKS kegiatan 1

12) Guru menayangkan sebuah gambar denah sebagai acuan mengerjakan LKS kegiatan 2

13) Siswa bersama kelompok mengerjakan LKS

14) Setiap kelompok mempresentasikan hasil kerjanya di depan kelas.

15) Guru bersama siswa membahas hasil kerja setiap kelompok

16) Guru mengadakan kuis lisan

17) Setiap siswa yang menjawab kuis dengan benar diberi sebuah bintang.

Pembelajaran 2

1) Guru melakukan tanya jawab tentang denah

2) Siswa mendengarkan penjelasan guru tentang kegiatan yang akan dilakukan selanjutnya.

3) Siswa duduk sesuai kelompok yang sudah dibagi sebelumnya

4) Siswa menyiapkan alat-alat yang akan digunakan untuk menggambar denah.

5) Siswa mengambil kertas yang disediakan oleh guru untuk menggambar denah,

6) Siswa bersama kelompok menggambar denah lingkungan sekolahnya

7) Guru mengotrol setiap kelompok

8) Siswa dibiarkan menuangkan imajinasinya pada denah gambarannya

9) Setiap kelompok mempresentasikan hasil kerjanya

10) Guru menayangkan gambar perilaku manusia menghemat air dan memboros air

11) Siswa menuliskan cara menghemat air

12) Siswa menceritakan cara menghemat air pada lembar kerja

13) Guru meminta beberapa siswa membacakan ceritanya masingmasing 
14) Siswa diberi tugas mengamati kebersihan air dilingkungan rumahnya

15) Siswa menuliskan hasil pengamatannya pada buku tugas untuk dikumpulkan dihari berikutnya

16) Siswa mengerjakan posttest dan lembar kuisioner

c. Observasi tindakan siklus I

Peneliti dibantu observer dalam mengadakan pengamatan selama proses pembelajaran berlangsung, peneliti dan observer samasama mengadakan pengamatan secara langsung dengan mengacu pada lembar observasi yang telah disiapkan. Lembar observasi digunakan untuk mengumpulkan data tentang dampak tindakan dalam aspek proses pembelajaran dari awal sampai akhir. Observasi dilakukan untuk mengamati partisipasi siswa dalam mengikuti pembelajaran.

\section{d. Refleksi siklus I}

Refleksi merupakan uraian tentang prosedur analisis terhadap hasil penelitian, refleksi berkaitan dengan proses dan dampak tindakan perbaikan bagi siklus berikutnya. Pada tahap ini data yang diperoleh pada saat observasi dan hasil pengisian kuisioner dianalisis untuk melihat minat dan kedisiplinan siswa selama partisipasi mengikuti pembelajaran. Data tersebut akan digunakan sebagai refleksi untuk melihat setelah tindakan ada peningkatan partisipasi dan kompetensi belajar atau tidak.

\section{Siklus II}

Siklus II dilaksanakan selama dua kali pertemuan, setiap pembelajaran terdapat $8 \times 35$ menit. Langkah-langkahnya sebagai berikut:

a. Perencanaan tindakan siklus II

Mempersiapkan perangkat pembelajaran dan menyusun perangkat pembelajaran berupa scenario pembelajaran yang akan digunakan pada siklus II meliputi Rencana Pelaksanaan Pembelajaran (RPP), lembar kerja sisiwa (LKS), pretest, posttest, kuis dan media pembelajaran. Setelah itu peneliti menyiapakn instrument penelitian untuk mengukur minat dan disiplin siswa berupa lembar observasi dan kuisioner. 
b. Observasi tindakan siklus II

Peneliti dibantu observer dalam mengadakan observasi selama proses pembelajaran brlangsung, peneliti dan observer secara bersamaan melakukan observasi secara langsung dengan mengacu pada lembar observasi yang telah disiapkan. Observasi dilakukan untuk mengamati partisipasi siswa dalam mengikuti pembelajaran dari awal sampai akhir.

\section{c. Refleksi}

Refleksi merupakan uraian tentang prosedur analisis terhadap hasil penelitian, refleksi berkaitan dengan proses dan dampak tindakan perbaikan bagi siklus berikutnya. Pata tahapan ini data yang diperoleh pada saat observasi dan hasil pengisian kuisioner dianalisis untuk melihat minat dan kedisiplinan siswa selama partisipasi mengikuti pembelajaran. Data tersebut akan digunakan sebagai refleksi untuk melihat efek setelah tindakan.

Pengumpulan data sangat diperlukan oleh peneliti untuk mengumpulkan data sesuai dengan tujuan penelitian. Menurut Arikunto data adalah hasil pencatatan peneliti, baik yang fakta ataupun angka. Pengumpulan data penelitian tindakan kelas ini dilakukan dengan tiga cara yaitu observasi,dokumentasi dan kuesioner ${ }^{43}$.

\section{1) Observasi}

Teknik ini digunakan untuk mengumpulkan data tentang dampak tindakan dalam aspek proses pembelajaran yang meliputi minat belajar dan disiplin siswa dalam pembelajaran. Menurut Hopkins dengan melakukan observasi peneliti akn memperoleh informasi sederhana yang dapat dikumpulkan, baik dengan sistem hitungan maupun dengan diagram ${ }^{44}$. Seorang guru diharuskan melakukan pengamatan terhadap tindakan dan perilaku erespon siswa di kelas. Safitri menyatakan observasi adalah pengumpulan data

${ }^{43}$ Arikunto, Suharsimi. "Metodelogi penelitian." Yogyakarta: Bina Aksara 44 Kumalaratih, Eko Beti. "PENINGKATAN HASIL BELAJAR ADMINISTRASI MENDESKRIPSIKAN PERKEMBANGAN SISTEN DISCOVERY LEARNING DENGAN METODE OBSERVASI DI KELAS VI SDN 3 SUMBERGIRANG." Jurnal Ilmiah Didaktika PGRI 2, no. 1 (2016): 111118. 
melalui pengamatan dan pencatatan bermanfaat bagi peneliti umntuk mendapat informasi yang digunakan sebagai bahan penelitian. Lembar observasi digunakan untuk mengamati kedisiplinan siswa, penilai memberi penilaian pada lembar observasi menggunakan turus ${ }^{45}$.

\section{2) Dokumentasi}

Dalam pengumpulan data peneliti juga merekam menggunakan perekam video untuk dokumentasi.selain itu peran video dan foto-foto ini membantu peneliti untuk melihat kembali proses pembelajaran secara lebih detail. Dokumentasi menggunakan video dan foto-foto digunakan untuk melengkapi data-data observasi yang dilakukan observer apabila terjadi kesalahan pengamatan ${ }^{46}$.

\section{3) Kuesioner}

Kuesioner merupakan teknik pengumpulan data yang dilakukan dengan cara memberi seperangkat pertanyaan atau peryataan tertulis kepada responden untuk dijawab. Peneliti menggunakan kuisioner untuk mendukung hasil pengamatan minat belajar dan kedisiplinan siswa selama mengikuti pelajaran Pkn. Kuesioner diisi oleh siswa kelas V sebanyak 3 kali yaitupada saat sebelum dilkukannya tindakan menggunakan model pembelajaran kooperatif tipe STAD untuk mendapatkan data minat belajar dan kedisiplinan sisw pada kondisi awal dan saat dilakukannya tindakan dengan model pembelajaran kooperatif tipe STAD untuk memperoleh data pada siklus 1 dan siklus 2 kuisioner diberikan pada saat berakhirnya pembelajaran.

Instrumen Penelitian Peneliti menggunakan lembar observasi untuk mengukur kedisiplinan siswa dalam mengikuti pembelajaran. Proses observasi memerlukan lembar observasi sebagai pedoman yang digunakan juga sebagai nilai afektif dan psikomotorik dari siswa dalam mengikuti pembelajaran. Dalam menyusun poin-poin observasi kedisiplinan, peneliti juga mengaitkan poin-poin tersebut dengan

${ }^{45}$ Safitri, Rani Okta, Susi Wendhaningsih, and Agung Kurniawan. "Teknik Penilaian Observasi Pada Ragam Gerak Tari Bedana Di SMP Wiyatama Bandar Lampung." Jurnal Seni dan Pembelajaran 6, no. 2 (2018).

${ }^{46}$ Khodijah, Syarifatun. "Pengaruh Tanggapan Siswa Tentang Penggunaan Kata Sapaan Guru Terhadap Motivasi Belajar Siswa Kelas V SD Negeri Ngarum 2 Kabupaten Sragen Tahun Pelajaran 2014/2015." PhD diss., Universitas Muhammadiyah Surakarta, 2015. 
indicator-indikator yang menunjukan kedisiplinan siswa dalam mengikuti pembelajaran Pkn.

\section{Kesimpulan}

Ikhtiar guru untuk melakukan perbaikan berkelanjutan dalam proses pembelajaran harus ditingkatkan. Masalah-masalah belajar yang dialami oleh siswa di SDN 18 Baruga telah memantik para guru untuk melakukan langkah-langkah progresif dengan memberikan tindakan (action) dalam kegiatan pembelajaran. Secara konseptual, upaya yang dilakukan merupakan praktik penelitian tindakan kelas, yang dalam artikel ini spesifik menyoroti perbaikan minat dan disiplin belajar siswa melalui penggunaan model pembelajaran kooperatif tipe STAD.

\section{Daftar Pustaka}

Aditya, Dedy Yusuf. "Pengaruh Penerapan Metode Pembelajaran Resitasi terhadap Hasil Belajar Matematika Siswa." SAP (Susunan Artikel Pendidikan) 1, no. 2 (2016).

Arikunto, Suharsimi. "Penelitian Tindakan Kelas (PTK)." Jakarta: Departemen Pendidikan dan Kebudayaan (2006).

Arikunto, Suharsimi. "Metodelogi penelitian." Yogyakarta: Bina Aksara (2006).

Aritonang, Keke T. "Minat dan motivasi dalam meningkatkan hasil belajar siswa." Jurnal pendidikan penabur 7, no. 10 (2008)

Astrawan, Kadek. "Implementasi Model Pembelajaran Kooperatif Tipe STAD Meningkatkan Aktivitas Dan Hasil Belajar Tolak Peluru." Jurnal Pendidikan Jasmani, Olahraga dan Kesehatan Undiksha 1, no. 1 (2013).

Astuti, Siwi Puji. "Pengaruh kemampuan awal dan minat belajar terhadap prestasi belajar fisika." Formatif: Jurnal Ilmiah Pendidikan MIPA 5, no. 1 (2015).

Astuti, Y., and Beni Setiawan. "Pengembangan lembar kerja siswa (LKS) berbasis pendekatan inkuiri terbimbing dalam pembelajaran kooperatif pada materi kalor." Jurnal Pendidikan IPA Indonesia 2, no. 1 (2013).

Aulina, Choirun Nisak. "Penanaman disiplin pada anak usia dini." PEDAGOGIA: Jurnal Pendidikan 2, no. 1 (2013) 
Badriyah, Nanik. "Penerapan pembelajaran kooperatif tipe STAD untuk meningkatkan hasil belajar IPS siswa kelas V MI Al Hikmah Beji Pasuruan." Penerapan pembelajaran kooperatif tipe STAD untuk meningkatkan hasil belajar IPS siswa kelas V MI Al Hikmah Beji Pasuruan/Nanik Badriyah (2010).

Chairani, Zahra. "Scaffolding dalam pembelajaran matematika." Math Didactic: Jurnal Pendidikan Matematika 1, no. 1 (2015).

Chulsum, Umi. "Pengaruh Lingkungan Keluarga, Kedisiplinan Siswa, Dan Motivasi Belajar Terhadap Hasil Belajar Ekonomi Siswa Di SMA Negeri 7 Surabaya." Jurnal ekonomi pendidikan dan Kewirausahaan 5, no. 1 (2017)

Fathurrohman, Muhammad. "Model-Model Pembelajaran." Universitas Negeri Yogyakarta. Jogjakarta: Ar-Ruzz Media. Retrieved from (2015).

Febrina, Nuansa Ayu, and Isroah Isroah. "Peningkatan Aktivitas Belajar Akuntansi Melalui Implementasi Model Pembelajaran Kooperatif Tipe Student Teams Achievement Division (STAD) Pada Siswa Kelas X Ak 3 Program Keahlian Akuntansi SMK Batik Perbaik Purworejo Tahun Ajaran 2011/2012." Jurnal Pendidikan Akuntansi Indonesia 10, no. 2 (2012).

Fimansyah, Dani. "Pengaruh Strategi Pembelajaran Dan Minat Belajar Terhadap Hasil Belajar Matematika." JUDIKA (JURNAL PENDIDIKAN UNSIKA) 3, no. 1 (2015).

Gunantara, Gede, I. Made Suarjana, and Putu Nanci Riastini. "Penerapan model pembelajaran problem based learning untuk meningkatkan kemampuan pemecahan masalah matematika siswa kelas V." MIMBAR PGSD Undiksha 2, no. 1 (2014).

Hasanah, Ummi, Riska Ahmad, and Yeni Karneli. "Efektivitas Layanan Penguasaan Konten untuk Meningkatkan Konsentrasi Belajar Siswa." (2017)

Hanafy, Muh Sain. "Konsep Belajar dan Pembelajaran." Lentera Pendidikan: Jurnal Ilmu Tarbiyah dan Keguruan 17, no. 1 (2014)

Hermawan, Andri. "Penerapan model pembelajaran kooperatif tipe stad untuk meningkatkan aktivitas dan hasil belajar IPS siswa kelas V SD Negeri Bandulan 05 Malang." Penerapan model pembelajaran kooperatif tipe stad untuk meningkatkan 
aktivitas dan hasil belajar IPS siswa kelas V SD Negeri Bandulan 05 Malang/Andri Hermawan (2012).

Kumalaratih, Eko Beti. "PENINGKATAN HASIL BELAJAR TENTANG MENDESKRIPSIKAN PERKEMBANGAN SISTEM ADMINISTRASI WILAYAH INDONESIA MELALUI PENDEKATAN DISCOVERY LEARNING DENGAN METODE OBSERVASI DI KELAS VI SDN 3 SUMBERGIRANG." Jurnal Ilmiah Didaktika PGRI 2, no. 1 (2016)

Kusrini, Woro, and Nanik Prihartanti. "Hubungan Dukungan Sosial dan Kepercayaan Diri dengan Prestasi Bahasa Inggris Siswa Kelas VIII SMP Negeri 6 Boyolali." Jurnal Penelitian Humaniora 15, no. 2 (2014)

Kusumaningsih, Kiki Dwi. "Pengaruh Model Pembelajaran Kooperatif Tipe Teams-Games-Tournaments (TGT) Terhadap Peningkatan Hasil Belajar Biologi Pada Konsep Sistem Pencernaan Manusia." Jurnal Ilmiah Exacta 2, no. 1 (2009)

Khodijah, Syarifatun. "Pengaruh Tanggapan Siswa Tentang Penggunaan Kata Sapaan Guru Terhadap Motivasi Belajar Siswa Kelas V SD Negeri Ngarum 2 Kabupaten Sragen Tahun Pelajaran 2014/2015." PhD diss., Universitas Muhammadiyah Surakarta, 2015.

KRITIS, BERPIKIR, and DAN PENGUASAAN KONSEP DALAM KONSEP FOTOSINTESIS. "A. Pembelajaran Kooperatif." (2003).

Lubis, Asneli. "Pengaruh Model Pembelajaran Kooperatif Tipe STAD Terhadap Hasil Belajar Fisika Siswa Pada Materi Pokok Gerak Lurus di Kelas X SMA Swasta UISU Medan." Jurnal Pendidikan Fisika 1, no. 1 (2012)

Miles, Matthew B., and A. Michael Huberman. "Analisis data kualitatif." (1992).

Moleong, Lexy J. "Metodologi penelitian kualitatif edisi revisi." Bandung: PT Remaja Rosdakarya 103 (2007).

Nuchiyah, Nunu. "Pengaruh Kepemimpinan Kepala Sekolah dan Kinerja Mengajar Guru Terhadap Prestasi Belajar Siswa." Jurnal Pendidikan Dasar 5, no. 7 (2007)

Nugroho, U., and S. S. Edi. "Penerapan pembelajaran kooperatif tipe STAD berorientasi keterampilan proses." Jurnal Pendidikan Fisika Indonesia 5, no. 2 (2009). 
Nurdyansyah, Nurdyansyah, and Toyiba Fitriyani. "Pengaruh Strategi Pembelajaran Aktif Terhadap Hasil Belajar Pada Madrasah Ibtidaiyah." Universitas Muhammadiyah Sidoarjo (2018).

Nurhasanah, Siti, and A. Sobandi. "Minat belajar sebagai determinan hasil belajar siswa." Jurnal pendidikan manajemen perkantoran 1, no. 1 (2016)

Rofiq, M. Nafiur. "Pembelajaran kooperatif (cooperative learning) dalam pengajaran pendidikan agama Islam." Jurnal Falasifa 1 , no. 1 (2010)

Rosnawati, R. "Enam tahapan aktivitas Dalam pembelajaran matematika untuk mendayagunakan berpikir tingkat tinggi siswa." In Jurnal disampaikan dalam seminar Nasional dengan tema: "Revitalisasi MIPA dan Pendidikan MIPA dalam Rangka penguasaan. 2009.

Safitri, Rani Okta, Susi Wendhaningsih, and Agung Kurniawan. "Teknik Penilaian Observasi Pada Ragam Gerak Tari Bedana Di SMP Wiyatama Bandar Lampung." Jurnal Seni dan Pembelajaran 6, no. 2 (2018).

Sanaky, Hujair AH. Setifikasi dan Profesionalisme Guru di Era Reformasi Pendidikan. Islamic University of Indonesia, 2005.

Sani, Ridwan Abdullah. "Inovasi pembelajaran." Jakarta: Bumi Aksara (2013)

Siagian, Roida Eva Flora. "Pengaruh minat dan kebiasaan belajar siswa terrhadap prestasi belajar matematika." Formatif: Jurnal Ilmiah Pendidikan MIPA 2, no. 2 (2015).

Sidanti, Heny. "pengaruh lingkungan kerja, disiplin kerja dan motivasi Kerja terhadap kinerja pegawai negeri sipil di Sekretariat DPRD kabupaten madiun." Jurnal Jibeka 9, no. 1 (2015)

Sjukur, Sulihin B. "Pengaruh blended learning terhadap motivasi belajar dan hasil belajar siswa di tingkat SMK." Jurnal pendidikan vokasi 2, no. 3 (2012).

Sugiyono. Metode penelitian pendidikan:(pendekatan kuantitatif, kualitatif dan $R \& D$ ). Alfabeta, 2008

Suharyat, Yayat. "Hubungan antara sikap, minat dan perilaku manusia." Jurnal Region 1, no. 3 (2009)

Supriadi, Oding. "Pengembangan profesionalisme guru sekolah dasar." Jurnal Tabularasa 6, no. 1 (2009)

Suryabrata, Sumadi. "Proses Belajar Mengajar di Perguruan Tinggi." Yogyakarta: Andi Ofset (1983). 
Suwastana, I. Wayan. "Penerapan Pembelajaran Melalui Model Kooperatif Numbered Heads Together Siswa Kelas V SDN No 1 Tonggolobibi Untuk Meningkatkan Prestasi Belajar PKn." Jurnal Kreatif Tadulako 4, no. 1 (2016).

Syatyawati, Riska. "Hubungan Antara Status Gizi dengan Prestasi Belajar Anak Sekolah Dasar di Desa Grenggeng Kecamatan Karanganyar Kebumen." PhD diss., Universitas Muhammadiyah Surakarta, 2013.

Widayati, Ani. "Penelitian tindakan kelas." Jurnal Pendidikan Akuntansi Indonesia 6, no. 1 (2008).

Winataputra, Udin Saripudin. "Materi dan pembelajaran PKn SD." (2014)

Zahrifah, Fitria Lailatus, and Eko Darminto. "Penggunaan Strategi Pengelolaan Diri untuk Meningkatkan Disiplin Belajar Siswa." Psikologi Pendidikan dan Bimbingan 12, no. 1 (2011). 